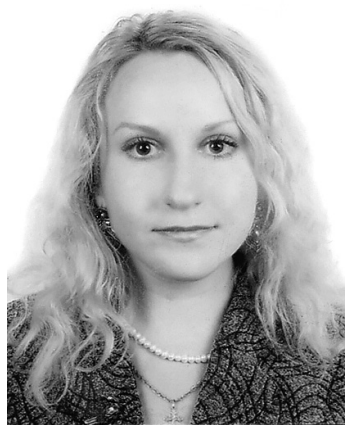

\title{
ДО ПИТАННЯ ПРО СУТНІСТЬ МІЖНАРОДНОГО ТРУДОВОГО IIPABA
}

\section{ШАШКОВА-ЖУРАВЕЛЬ І.О. - доктор філософї̈ права, професор МКА, заступник завідувача кафедри міжнародного права та порівняльного правознавства Н.Н. Інституту права МАУП \\ DOI:10.32782/NP.2019.4.19}

Дана наукова стаття спрямована на комплексний аналіз багатоманітної наукової думки щздо поняття міжнародного трудового права та розуміння його місия в системі міжнародного права. Окрема увага в даній науковій статті звертається на висвітлення суспільного призначення міжнародного трудового права на сучасному етапі розвитку світового співтовариства. Також, автори пропонують власне визначення поняття міжнародного трудового права.

Ключові слова: міжнародне трудове право, міжнародно-правове регулювання прачі, поняття міжнародного трудового права, суспільне призначення міжнародного трудового права.

\section{Постановка проблеми}

На сучасному етапі вважається загальновизнаним те, що людина не може почуватися дійсно вільною без належного рівня захищеності іiі соціально-економічних прав, центральним елементом яких $\epsilon$ трудові права. Відтак, не викликає сумніву важливість для світового співтовариства системи міжнародно-правових норм, спрямованих на захист відносин праці. В науці міжнародного права, на даний час, відсутня єдність поглядів стосовно сутності міжнародного трудового права та його місця в системі міжнародного права, що обумовлює актуальність подальших наукових досліджень в даному напрямі.

\section{Аналіз останніх досліджень}

\section{і публікацій}

Питання сутності міжнародного трудового права, його специфіки та місця в системі міжнародного права знаходило відображення в працях таких вітчизняних та зарубіжних вчених як В.М. Андріїв, А.М. Аметистов, О.Ю. Білоус, Д.К. Бекяшев, Д.М. Величко, О.С. Волохов, Г.А. Капліна, І.Я. Кісельов, С.С. Аукаш, М.В. Аушникова, Н.А. Аютов, П. Є. Морозов, Ю.В. Чижмарь, О.В. Чорноус, I.I. Яцкевич та ін. Однак, в науці міжнародного права триває дискусія стосовно багатьох аспектів міжнародного регулювання праці, що засвідчує необхідність подальших наукових досліджень галузі міжнародного трудового права.

\section{Формулювання цілей статті.}

Метою даної наукової статті $є$ комплексний аналіз плюралістичної наукової думки щодо поняття міжнародного трудового права та його місця в системі міжнародного права. Вказаною метою було обумовлено наступні завдання наукової статті:

- аналіз наукових поглядів щодо розуміння сутності міжнародного трудового права та його статусу в системі сучасного міжнародного права;

- висвітлення наукової думки про суспільне призначення міжнародного трудового права в сучасних умовах розвитку світового співтовариства;

- формулювання власного бачення сутності міжнародного трудового права та 


\section{Міжнародне право}

співвідношення категорій «міжнародне трудове право» та « міжнародно-правове регулювання праці».

\section{Виклад основного матеріалу}

Досліджуючи сутність міжнародного трудового права, насамперед, слід звернути увагу на відсутність єдності поглядів вчених стосовно місця міжнародного трудового права в системі міжнародного права. Так, більшість вчених - міжнародників схиляються до визнання міжнародного трудового права самостійною галуззю сучасного міжнародного права, однак, значна кількість науковців утримуються від визнання за міжнародних трудовим правом статусу самодостатньої галузі міжнародного права та застосовують в своїх працях категорію «міжнародно-правове регулювання праці». Також, в міжнародно-правовій науці має місце бачення системи міжнародно-правового захисту соціально-економічних, в тому числі, трудових прав як одного із інститутів галузі міжнародного права прав людини.

Слід зазначити, що вченими, які одні із перших на теренах колишнього СРСР досліджували проблематику міжнародного трудового права були Е.М. Аметистов та С.О. Іванов. Так, С.О. Іванов в 60-роках 20 століття дійшов висновку про обгрунтованість відокремлення міжнародного трудового права в самодостатню галузь міжнародного права та пропонував розглядати міжнародне трудове право як окрему специфічну галузь міжнародного права, спрямовану на забезпечення державного співробітництва з метою поліпшення умов праці громадян [1; С. 102-103]. Е.М. Аметистов вбачає в міжнародному трудовому праві підгалузь міжнародного права, що спрямована на регулювання відносин між державами 3 метою захисту трудових прав [2; C. 10]. Вчений визначає мету здійснюваного за допомогою міжнародних трудових норм міжнародного регулювання праці як забезпечення захисту трудових прав працівників та їх професійних організацій шляхом встановлення певних юридичних і фактичних гарантій трудових прав, за рахунок чого досягається покращення умов праці та побуту трудящих в різних державах [3; С. 5-6].

Слід відмітити, що ряд науковців надають перевагу формулюванню «міжнародноправове регулювання праці». Так, змістовне та достатньо конкретизоване визначення даного поняття було запропоновано І.Я. Кісельовим. На думку вченого, міжнародноправове регулювання праці являе собою здійснювану за допомогою міждержавних угод регламентацію питань, пов'язаних із застосуванням найманої праці, охорони праці, покращення умов праці, а також захистом колективних та індивідуальних інтересів працівників. Головним результатом міжнародно-правового регулювання праці вчений вважає вироблення міжнародних трудових стандартів, що являють собою нормативний елемент міжнародного трудового права, змістом якого є ретельно відібрані найбільш універсально-значущі принципи та норми, що властиві національним системам трудового права, являють собою вираз досвіду багатьох поколінь та відображають результати виробленої світовою спільнотою соціальної політики, а також державної діяльності, спрямованої на запровадження соціальних цінностей до ринкової економіки [4; С.448-449].

Згідно визначення О.С. Волохова, міжнародно-правове регулювання праці являє собою застосування положень міжнародноправових актів у сфері праці до відносин праці та пов'язаних з ними відносин, що мають місце в межах держави або виникають у зв'язку із діяльністю транснаціональної корпорації [5; С. 346-351]. Ми не можемо повністю погодитись із запропонованим визначенням міжнародно-правового регулювання праці з огляду на належність транснаціональних корпорацій до суб'єктів міжнародного приватного права.

Відомий український правознавець Ю.В. Чижмарь визначає міжнародне трудове право як систему правових актів, за допомогою яких здійснюється закріплення міжнародних стандартів праці, принципів у сфері праці, міжнародних зобов'язань держав щодо регулювання відносин праці, а також актів міжнародних організацій, спрямованих на здійснення регулюючого 
впливу на різні держави. Вчений зазначає, що елементами міжнародного трудового права виступають міждержавні угоди, міжнародні стандарти, акти міжнародних інституцій, що здійснюють регулюючий вплив, а також практика міжнародних судових установ. Ми повністю поділяємо думку Ю.В. Чижмаря, який головною метою міжнародного трудового права вбачає сприяння покращенню умов праці трудящих у світі, збільшити можливості якого видається можливим за рахунок економічного та соціального прогресу, досягнення якого потребує миру та стабільності у міжнародному співтоваристві. Також, вчений стверджує, що в сучасний період відбувається остаточне формування міжнародного трудового права як самодостатньої галузі міжнародного права та звертає увагу на те, що норми міжнародного трудового права реалізуються завдяки вольовим зусиллям держав. До головних суб'єктів міжнародного трудового права Ю.В. Чижмарь справедливо відносить держави, при цьому, зазначаючи можливість включення до кола суб'єктів міжнародного трудового права міжнародних неурядових організацій наступних видів:

- міжнародних профспілкових організацій;

- міжнародних організацій роботодавців;

- правозахисних організацій міжнародного рівня (у зв'язку із реалізацією трудових прав)[6].

На думку С.С. Аукаш, міжнародно-правове регулювання праці являє собою сукупність норм міжнародного права, спрямованих на встановлення стандартів у сфері праці та зайнятості, остаточною метою яких є забезпечення впливу на внутрішньодержавне трудове право з метою його вдосконалення. Міжнародне трудове право, на думку вченого, є галуззю міжнародного права, що включає особливу систему правових норм, спрямованих на регулювання відносин між суб'єктами міжнародного права 3 метою захисту трудових прав працівників та їх представницьких організацій, покращення побуту та умов праці трудящих, що здійснюеться за допомогою встановлення правових та фактичних гарантій трудових прав на підставі рівності [7].

Також, досить вдало, на наш погляд, розмежовує поняття «міжнародне трудове право» та «міжнародно-правове регулювання праці» провідний український вчений в галузі трудового права В.М. Андріїв, який зазначає, що «міжнародне трудове право» слід розглядати як правовий вираз діяльності міжнародних організацій щодо регулювання сфери відносин праці. Головна увага, при цьому, зосереджена на міжнародних стандартах праці, їх змісті, цілях, тенденціях розвитку, а також механізмі реалізації. Також, вчений вказує на можливість розуміння міжнародного трудового права у «вузькому» значенні як тієї його частини, що знаходить місце в праві конкретної держави за рахунок конституційних норм, норм національного трудового законодавства, а також існуючих правових процедур та міжнародно-правових правил. Натомість, поняття «міжнародно-правове регулювання праці» є категорією, що охоплює не тільки міжнародні трудові норми, а, також, норми інших міжнародно-правових інститутів та галузей, які здійснюють вплив на регулювання сфери праці та механізм правового регулювання, яке здійснюється за допомогою вказаних норм [8; С. 12]

Ми погоджуємось 3 баченням I.I. Яцкевича про недоцільність ототожнення сукупності міжнародно-правових норм, що спрямовані на встановлення міжнародних трудових стандартів з правовим регулюванням, яке не просто включає міжнародноправові норми, а являє собою організовану систему міжнародно-правових актів, приймаючи та застосовуючи які суб'єкти міжнародного права мають можливість здійснювати вплив на відносини праці (часто такий вплив здійснюється опосередковано в результаті національної імплементації міжнародно-правових норм про працю). Вчений пропонує розглядати міжнародно-правове регулювання трудових відносин в широкому та у вузькому розумінні. Так, у широкому розумінні зазначене поняття являє собою діяльність суб'єктів міжнародного права, а також результат їх діяльності у вигляді системи міжнародно-правових актів, що визна- 


\section{Міжнародне право}

чають зміст міжнародно-правового регулювання відносин праці. У вузькому розумінні міжнародно-правове регулювання трудових відносин є системою міжнародно-правових актів, нормативні положення яких мають на меті правове впорядкування трудових відносин [9].

Слід вказати на те, що ряд вчених - міжнародників виокремлюють в міжнародному трудовому праві як публічну так і приватну складові. Так, на думку співавторів Н. $\curlywedge$. Лютова і П.Е Морозова міжнародне трудове право поділяється на міжнародне публічне трудове право та міжнародне приватне трудове право. Вчені обгрунтовують таке бачення сутності міжнародного трудового права поділом, власне, міжнародного права на міжнародне публічне та міжнародне приватне право. Так, міжнародне публічне трудове право співавтори розглядають як сукупність загальновизнаних міжнародноправових на національно-правових принципів та норм, міжнародних договорів, актів «міжнародного м'якого права», що має на меті запровадження і застосування міжнародних трудових стандартів. В свою чергу, міжнародне приватне трудове право, на думку вчених являє собою систему правових норм, що регулюють відносини праці інші тісно пов'язані з ними відносини, що ускладнені іноземним елементом, відносини щодо дотримання актів транснаціональних корпорацій у сфері праці, а також міжнародні соціально-партнерські відносини [10; C.8-9 ].

На нашу думку, сутність міжнародного трудового права досить вдало відображена у визначенні Д.К. Бекяшева, який пропонує розглядати міжнародне трудове право як галузь міжнародного публічного права, яка являє собою сукупність міжнародно-правових норм, спрямованих на регулювання відносин між суб'єктами міжнародного права стосовно трудових прав, зайнятості індивідів, їх умов праці, а також соціального забезпечення та соціального партнерства [11; C. 13].

Досліджуючи суспільне призначення міжнародного трудового права, варто погодитись з М.В. Аушниковою, яка вказує на те, що соціальне призначення міжнародно- го трудового права, яке початково мало на меті забезпечення міжнародними зусиллями охорону праці та захист трудових прав працівників та їх організацій, зберігається і на сучасному етапі. На думку вченої, сучасне міжнародне трудове право покликано забезпечувати регулювання міжнародних відносин 3 метою захисту трудових прав індивідів за допомогою міжнародно-правових засобів. Предмет міжнародного трудового права, на думку М.В. Аушникової охоплюе наступні основні групи міжнародних відносин:

- міжнародні відносини 3 приводу прийняття міжнародно-правових актів, які містять міжнародні стандарти праці і міжнародні колізійні норми;

- міжнародні відносини, змістом яких є забезпечення міжнародного контролю щодо дотримання та виконання приписів міжнародно-правових актів про працю [12].

Як справедливо зазначає М.М. Грекова, на сучасному етапі міжнародно-правове регулювання праці не обмежується закріпленням трудових прав людини на міжнародному рівні, а потребує, також, розробки механізму національної імплементації міжнародних трудових прав. На думку вченої, міжнародно-правове регулювання праці характеризується поєднанням статичного та динамічного аспектів. Так, статичний аспект, передбачає закріплення міжнародних трудових стандартів на рівні міжнародно-правових актів, насамперед, міжнародних договорів, а динамічний аспект включає процес здійснення приписів вказаних міжнародних договорів на рівні національних законодавств держав [13].

На нашу думку, позитивним в зазначеному баченні предмета міжнародного трудового права слід відмітити включення до його структури відносин контролю за реалізацією міжнародних норм про працю. Поза сумнівом те, що існуючий в рамках міжнародного трудового права контрольний механізм є необхідною складовою системи забезпечення ефективної реалізації міжнародних норм про працю.

Потрібно зазначити, що, на наш погляд, досить повне та змістовне визначення 
принципів, властивих міжнародного трудовому праву наводить Г. А. Капліна. Так, вчена пропонує розглядати принципи міжнародного трудового права як імперативні засади у сфері праці, що визнані світовою спільнотою, відображені на рівні декларацій та статутних норм міжнародних організацій універсального характеру - ООН та Міжнародної організації праці, обов'язкові для їх держав-учасниць, є такими, що визначають національні системи трудового права та законодавства та є забезпеченими засобами реагування міжнародного співтовариства у випадку їх не додержання. Г. А. Капліна слушно окреслюе масив універсальних міжнародно-правових актів, що виступають джерелами принципів міжнародного регулювання праці. Вказані міжнародно-правові документи включають Статут Міжнародної організації праці, Філадельфійську Декларацію «Про цілі та завдання Міжнародної організації праці» від 1944 року, Декларацію Міжнародної організації праці «Про основоположні принципи та права у сфері праці» від 1998 року, Декларацію Міжнародної організації праці «Про соціальну справедливість 3 метою справедливої глобалізації» від 2008 року. До принципів міжнародного трудового права вчена відносить:

- принцип соціальної справедливості, що передбачає можливість всіх індивідів брати участь в справедливому розподілі результатів суспільного прогресу, включаючи умови праці та інші аспекти захисту праці;

- принцип свободи асоціації у сфері праці стосовно як працівників так і роботодавців;

- принцип гуманізму у сфері праці, що, зокрема, передбачає необхідність поліпшення умов праці на загальносвітовому рівні та затверджує важливість подолання бідності у світі;

- принцип рівної оплати за рівну праЦЮ;

- принцип співпраці соціальних партнерів;

- принцип визнання свободи праці;

- принцип не визнання праці товаром

\section{Висновки}

На підставі аналізу плюралістичної наукової думки про сутність міжнародного трудового права та його місце в системі міжнародного права є можливість констатувати наступне:

- міжнародне трудове право являє собою окрему галузь міжнародного (міжнародного публічного) права, що є системою забезпечених контрольним механізмом Міжнародної організації праці універсальних міжнародно-правових принципів у сфері праці, загальносвітових та спрямованих на їх відображення та деталізацію регіональних міжнародних трудових норм, регулюючий вплив якої спрямований на сприяння ефективному затвердженню та захисту індивідуальних та колективних трудових прав індивідів державами світового співтовариства;

- поняття «міжнародно-правове регулювання праці» доцільно застосовувати для позначення регулюючого впливу, що здійснюється на сферу трудових відносин у світі, а також діяльності, що спрямована на створення норм та принципів міжнародного трудового права, насамперед, діяльності здійснюваної в рамках Міжнародної організації праці. В широкому розумінні «міжнародне трудове право» $\mathrm{i}$ «міжнародно-правове регулювання праці» можуть вживатись як ідентичні поняття 3 огляду на спільне суспільне призначення категорій, що ними позначаються;

- головною метою сучасного міжнародного трудового права є досягнення поєднання економічного та соціального прогресу, а також подолання бідності у світі, що може бути забезпечено шляхом здійснення регулюючого впливу на діяльність держав-учасниць світового співтовариства, насамперед, в таких напрямах як забезпечення ефективної зайнятості, протидія дискримінації в галузі праці, заборона примусової праці, затвердження та захист права на асоціацію у сфері праці, охорона праці, а також забезпечення гідної винагороди за працю. [14]. 


\section{Аітература}

1. Иванов С. А. Проблемы международного регулирования труда. - М.: Изд. «Наука», 1964.- 343 с.

2. Аметистов Э.М. Международное трудовое право и рабочий класс. М.: Международные отношения, 1970. 186 с.

3. Аметистов Э. М. Международное право и труд: Факторы имплементации международных норм о труде / Э. М. Аметистов. - М.: Междунар. отношения, 1982. 352 c.

4. Кисилев И.Я. Сравнительное и международное трудовое право. Учебник для вузов. - М.: Дело, 1999. - 728 с.

5. Волохов О. С. Міжнародно-правове регулювання праці: поняття та принципи / О. С. Волохов // Держава і право : 3бірник наукових праць. Юридичні і політичні науки. Випуск 56. - К. : Інститут держави і права ім. В. М. Корецького НАН України, 2012. - 680 c.

6. Національне та міжнародне трудове право: теоретико-правові проблеми [Текст] : автореф. дис. ... д-ра юрид. наук : 12.00.05 / Чижмарь Юрій Васильович ; Київ. нац. ун-т ім. Тараса Шевченка. - Київ, 2016. - 36 с.

7. Аукаш С. С. Міжнародно-правове регулювання в сфері праці / С. С. Аукаш // Юридична наука і практика. - 2011. - № 2. C. 28-34.

8. Андріїв В. М. Міжнародне трудове право: навчальний посіб. / В. М. Андріїв. -Київ : ВД «Дакор», 2017. - 574 с.

9. Яцкевич I. I. Поняття та особливості міжнародно-правового регулювання юридичних гарантій у сфері праці / I. I. Яцкевич. // Часопис Національного університету «Острозька академія». Сер. : Право. - 2014. - № 2. - Режим доступу: http://nbuv.gov.ua/ UJRN/Choasp_2014_2_36.]

10. Аютов Н. А., Морозов П. Е.. Международное трудовое право: учебное пособие / Москва: Проспект.2011. -216 с.

11. Бекяшев Д. К. Международное трудовое, право. Публично-правовые аспекты. - М.: Проспект, 2013.- 1008 с.

12. Аушникова М.В. Международное трудовое право: понятие, предмет / М.В. Аушникова// Весник пермского университета, Выпуск 3 (21), 2013. С.131-138
13. Грекова М.М. Поняття та зміст міжнародно-правового регулювання відносин у сфері праці / М.М. Грекова // Юридична Україна № 11, 2012. С. 110-114

14. Капліна Г.А. Роль принципів та норм міжнародного трудового права в сучасних інтеграційних процесах / Г.А. Капліна // Европейські інтеграційні процеси у XXI столітті : ключові тенденції, основні виклики та нові можливості : збірник матеріалів Міжнар. наук.-практ. конф. (м. Київ, 26-27 березня 2018 р.). - К.: Українська Асоціація Викладачів і Дослідників Европейської Інтеграції. С. 234-244..

This article aims at a comprehensive analysis of the diverse scientific thought of defining the concept of international labor law and understanding its place in the system of international law. The authors draw attention to the lack of unity of views of scientists regarding the essence and the ratio between the concepts of "international labor law" and "international legal regulation of labor", as well as the place of international labor law in the system of international law. Thus, the majority of international scholars tend to recognize international labor law as an independent branch of modern international law, however, a significant number of scholars refrain from recognizing international labor law as a self-sufficient field of international law and apply in their works the category of «international legal regulation of labor». Also, in the international legal science there is a vision of «the system of international legal protection of socio-economic, including labor rights» as one of the institutes of the field of international human rights law. The authors agree with the scientific opinion on the attachment of international labor law to international public law.

Particular attention in this scientific article is drawn to the coverage of the social purpose of international labor law at the present stage of development of the world community. The authors share the scientific opinion regarding the vision of the social purpose of international labor law in providing international efforts through international legal means of labor 
protection and the protection of labor rights of workers and their organizations.

Also, the authors provide their own vision of the essence and the social purpose of international labor law based on the analyzes of the pluralistic scientific thought. Thus, the authors state the following:

- international labor law constitutes a separate branch of international (international public) law, which is a system of universal international legal principles, guaranteed by the International Labor Organization, in the field of labor, universal and aimed at their reflection and the elaboration of regional international labor norms whose regulatory influence is directed to promote the effective approval and protection of individual and collective labor rights of individuals by states of the world community;

- The concept of "international legal regulation of labor" should be used to refer to regulatory influence on the field of labor relations in the world, as well as activities aimed at the establishment of norms and principles of international labor law, in particular, activities carried out within the framework of the International Labor Organization. In the broad sense, «international labor law» and «international legal regulation of labor» can be used as identical concepts in view of the common social assignment of the categories which are affected by them;

- The main objective of modern international labor law is to achieve a combination of economic and social progress, as well as overcoming global poverty, which can be achieved by regulating the work of the member states of the world community first of all in such areas as ensuring effective employment, combating discrimination in the field of labor , the prohibition of forced labor, the approval and protection of the right to association in the field of labor, labor protection, as well as the provision of decent remuneration for work.

Key words: international labor law, international legal regulation of labor, concept of international labor law, public appointment of international labor law. 